\title{
PARALYTIC RABIES IN SWINE
}

\section{Clarice Ricardo de Macedo Pessoa ${ }^{1}$, Maria Luana Cristiny Rodrigues Silva ${ }^{1}$, Albério Antônio de Barros Gomes ${ }^{1}$, Andrea Isabel Estévez Garcia ${ }^{2}$, Fumio Honma Ito ${ }^{2}$, Paulo Eduardo Brandão ${ }^{2}$, Franklin Riet-Correa ${ }^{{ }^{*}}$}

\author{
${ }^{1}$ Unidade Acadêmica de Medicina Veterinária, Centro de Saúde e Tecnologia Rural, Universidade Federal de Campina Grande, \\ Patos, PB, Brasil; ${ }^{2}$ Departamento de Medicina Veterinária Preventiva e Saúde Animal, Faculdade de \\ Medicina Veterinária e Zootecnia, Universidade de São Paulo, São Paulo, SP, Brasil.
}

Submitted: April 13, 2010; Returned to authors for corrections: May 11, 2010; Approved: June 21, 2010.

\begin{abstract}
Rabies transmitted by vampire bats was diagnosed in pigs with paralysis of the pelvic limbs. Diffuse nonsuppurative encephalomyelitis, affecting mainly the spinal cord, was observed histologically. Despite the various diagnosis of rabies in pigs this is the first report of clinical signs and pathology of rabies transmitted by vampire bats.
\end{abstract}

Key word: vampire bats, epidemiology, virus isolation, zoonotic.

Rabies is rare in swine and there are few reports on the epidemiologic, clinical and pathologic characteristics of the disease in this species. In an outbreak of swine rabies transmitted by a dog in China the main clinical signs were aggressiveness and other cerebral signs (9). In USA, in 10 cases of rabies transmitted by wild animals, mainly raccoons, mongoose and skunks, clinical signs were fever, aggression, restlessness, ptyalism, anorexia, head rubbing, progressive paralysis, depression, and vocalization (5).

In Brazil there are several reports of identification of rabies virus in swine mainly from the states of Pará (2), Tocantins (18), Goias (8), Mato Grosso (15) Rio Grande do Sul (21) and São Paulo (17), but there are no reports on the epidemiology, clinical signs and pathology of the disease in this species. Some of those viruses were originated from dogs (8) and others from vampire bats (2). The objective of this paper is to report, for the first time, the epidemiology, clinical and pathology of an outbreak of rabies transmitted by vampire bats in swine.
In June 2009, the Pathology Section of the Veterinary Animal Hospital belonging to the Federal University of Campina Grande, state of Paraíba, received two pigs presenting neurological signs. The two animals were raised in a piggery with other 28 pigs of different ages, in the municipality of Mãe D’Água, in the semiarid of Paraíba. Both animals were submitted to euthanasia and necropsied. Samples of tissues from the thoracic and abdominal cavities, the whole brain and spinal cord of a pig, and half brain and spinal cord of another pig were fixed in $10 \%$ buffered formalin. The tissues samples and samples of transverse sections of the CNS including the spinal cord (cervical, thoracic and lumbar), cerebellum, cortex, cerebellar peduncles, medulla oblongata, pons, rostral and caudal colliculi, hippocampus, thalamus, basal nuclei and internal capsule were embedded in paraffin, sectioned in 4-5 $\mu \mathrm{m}$ slices and stained with hematoxylin- eosin for histological examination. The trigeminal ganglia from Pig 2 were also studied histologically.

\footnotetext{
*Corresponding Author. Mailing address: Unidade Acadêmica de Medicina Veterinária, Centro de Saúde e Tecnologia Rural, Universidade Federal de Campina Grande, Av. Universitária, Bairro Santa Cecília, CEP 58700-970, Caixa Postal 64, Patos, Paraíba, Brazil.; E-mail: franklin.riet@pq.cnpq.br
} 
From Pig 2, fragments of the CNS including the spinal cord (cervical, thoracic and lumbar), cerebellum, cortex, cerebellar peduncles, medulla oblongata, pons, rostral and caudal colliculi, hippocampus, thalamus, basal nuclei and internal capsule were examined for rabies through the direct fluorescent antibody test (FAT) and mouse inoculation test (MIT). For the MIT, the suspensions were individually macerated and diluted to make a $20 \%$ suspension (weight/volume) with a solution of sterilized distilled water containing $2 \%(\mathrm{v} / \mathrm{v})$ rabbit sera, penicillin $(500 \mathrm{UI} / \mathrm{mL})$ and streptomycin $(1,560 \mathrm{UI} / \mathrm{mL})$. After centrifuging at 2,000 $\mathrm{G}$ for 10 minutes, a volume of $0.03 \mathrm{~mL}$ was inoculated intracerebrally in groups of ten mice, according to Koprowski (10). Mice were daily observed for 30 days for rabies signs, and the confirmation of rabies was by the FAT. Mice used for diagnostic and virus isolation procedures were 21 day-old Swiss albino, lineage CH3 Rockefeller, weighing 11-15 g, and maintained at the Federal University of Campina Grande facilities. The FAT was performed according to the technique of Goldwasser \& Kissling (6) modified by Dean et al.(4). The rabies conjugate was provided by the Pasteur Institute of São Paulo - SP, Brazil, lot IP-CAR TOT 03/08. The historical and clinical data were obtained by interviewing the owner, and the epidemiological information was completed after the inspection of the piggery.

The rabies virus isolated from swine identified as PN169PB was submitted to RNA extraction from a $10 \%$ viral suspension, using Trizol® (Invitrogen $®$ ), according to the manufacturer's instructions. RT-PCR was carried out as described by Macedo et al.(12), using sense primer 504 (5'TATACTCGAATCATGATGAATGGAGGTCGACT-3') and antisense primer 304 (5',-TTGACGAAGATCTTGCTCAT-3') targeted to the nucleoprotein gene, with a predicted amplicon of 264bp in the 3'region of the gene, close to the $\mathrm{P}$ gene, and M-MLV Reverse Transcriptase ${ }^{\mathrm{TM}}$ and Platinum ${ }^{\mathrm{TM}}$ Taq DNA Polymerase (Invitrogen) according to manufacturer's instructions.

The amplicon was sequenced with both primers using BigDye $3.1^{\mathrm{TM}} \quad$ (Applied Biosystems) according to manufacturer's instructions and the sequences were obtained in an ABI-377 ${ }^{\mathrm{TM}}$ automatic sequencer (Applied Biosystems).

For the construction of a dendrogram, DNA sequences retrieved from Genbank were employed and aligned by CLUSTAL/W method, using the Bioedit 7.0.9.0 program. and a nucleotide distance tree was generated with the NeighborJoining algorithm and MCL model using the MEGA software with 1000 bootstrap repetitions (20).

The first animal to show clinical signs (Pig 1) was a 45 days-old male pig, showing flacid paralysis of the pelvic limbs during two days, which was presumptively diagnosed as trauma. At necropsy, gross lesions were not observed. Upon histological examination, non-suppurative encephalomyelitis with perivascular cuffs composed by lymphocytes, plasma cells and rare macrophages, diffuse or multifocal gliosis, neuronophagia, hemorrhages and vasculitis were observed notably in gray matter (Fig. 1). These lesions were mild in all regions of brainstem, severe in spinal cord and absent in the telencephalon. Since the lesions were similar to those of rabies, a visit to the farm was made to get additional epidemiological data. During the visit, another animal (Pig 2) was found with nervous signs and conducted to the Veterinary Hospital. It was a 30 month-old pregnant sow, and the signs started 8 days before the visiting day. It showed anorexia and paresis followed by paralysis of the pelvic limbs and tail (Fig. 1D). During examination was in lateral recumbence, adopting a sitting dog position when forced to stand. The cutaneous sensitivity and cutaneous trunci reflex were severely decreased. At necropsy, no significant lesions were observed. The histological lesions were non-suppurative encephalomyelitis, meningitis, and trigeminal ganglioneuritis, with the same cell characteristics observed in Pig 1 (Fig.1). Those lesions were mild in telencephalon and cerebellum and severe in brainstem and spinal cord. The leptomeninges were diffusely infiltrated by mononuclear cells with presence of perivascular cuffings.

All the fragments examined were negative by the FAT and the samples of the thalamus, pons, medulla oblongata and cervical, thoracic and lumbar medulla were positive by MIT. The swine virus isolated showed maximum nucleotide identity 
with bovine rabies virus transmitted by $D$. rotundus bats of the São Paulo State after DNA sequencing and phylogenetic analysis.

The place where the pigs were raised (Fig. 2A) was located in the neighboring of the town (Fig. 2B) and the pigs were feed mainly with home residues. The town is surrounded by mountains with caves, rocks and covered by the native forest (caatinga) typical of the semiarid region (Fig. 2 B-D). No vaccination or deworming had been done before the rabies outbreak. The owner remembered that approximately 6 months ago he noted the presence of a bat inside the pen and the signal of blood feeding in one animal. After the confirmation of rabies diagnosis, he was advised to vaccinate the remaining animals. Eight days after vaccination with a commercial rabies vaccine (raivacel® -Vallée) an adult sow showed clinical signs similar to those observed in the previous cases, but recovered in 10-12 days. No more cases were observed later.

In Brazil, rabies is frequently diagnosed in cattle and horses (11). Sheep and goats are less common affected (11) and the disease is rare in swine. In absence of cattle and horses, which are favorite source for vampire bats, other species, including swine are alternative source of food for $D$. rotundus $(1,22)$. Despite the reports on the isolation of rabies virus in swine there are only rare reports on the clinical signs of the disease in this species. In an outbreak of rabies transmitted initially by a dog, the main clinical signs were aggressiveness, hyper excitation, and roaring, with a furious rabies pig jumping the pen wall to bite other pigs, which were later affected with a furious form of the disease (9). In contrast, in the outbreak reported in this paper clinical signs were exclusively of the paralytic form, similar to that observed in most cases of bovine rabies (11). Those clinical signs are due to the distribution of the lesions in the affected animals which showed severe lesions on the spinal cord in both animals, mild (Pig 1) or severe (Pig 2) lesions of the brain stem, and absence (Pig 1) or mild lesions (Pig 2) in the telencephalon.

The sensibility of FAT for the diagnosis of pig rabies is questioned. Yates et al. (22) found four pigs negative for FAT but positive for MIT. Prins and Yates (16) analyzed 11 pigs, only one was FAT-negative, but all of them were MITpositives. Also the absence of Negri bodies in the cases reported in this paper and in other reports (13), indicates the difficulties in the diagnosis of rabies in swine, and the importance of the differential diagnosis with other swine viral encephalitis with lesions similar to those of rabies (19). The rapid diagnosis of rabies transmitted by bats in swine is also very important because, in some occasions, human cases of rabies transmitted by vampire bats were preceded by swine cases (14).

The genetic typing of the isolate revealed that the virus is suggested that the transmitter was a D. rotundus bat as the swine rabies virus isolate in this study was phylogenetically related to rabies virus isolated most frequently from the $D$. rotundus vampire bats in Brazil. According to Ito et al. (8), the strain-specific reverse transcriptase-polymerase chain reaction and restriction fragment length polymorphism analysis could discriminate Brazilian rabies virus isolates into dog-related and vampire bat-related viruses and the sequencing of PCR products can reveal the probable origin of the animal transmitter. The swine isolate of this study was genetically and phylogenetically related to the rabies virus isolated most frequently from the D. rotundus vampire bats in Brazil. The existence of caves in the region favors the presence of vampire bats and, consequently, the transmission of the virus to other animal hosts, including wild animals, which perpetuates the presence of virus in the Brazilian semiarid region (7). Due to the seriousness of the disease, it is important to reinforce the vaccination of all farm animals, including pigs, to prevent the disease in animals and man. The Pasteur Institute of São Paulo registered from 1980 to 1995 , one case of human rabies transmitted by a pig, which is considered an animal offering a median risk (3). As a consequence in any pig with neurological signs rabies is an alternative diagnostic, and there is the possibility of human transmission. 


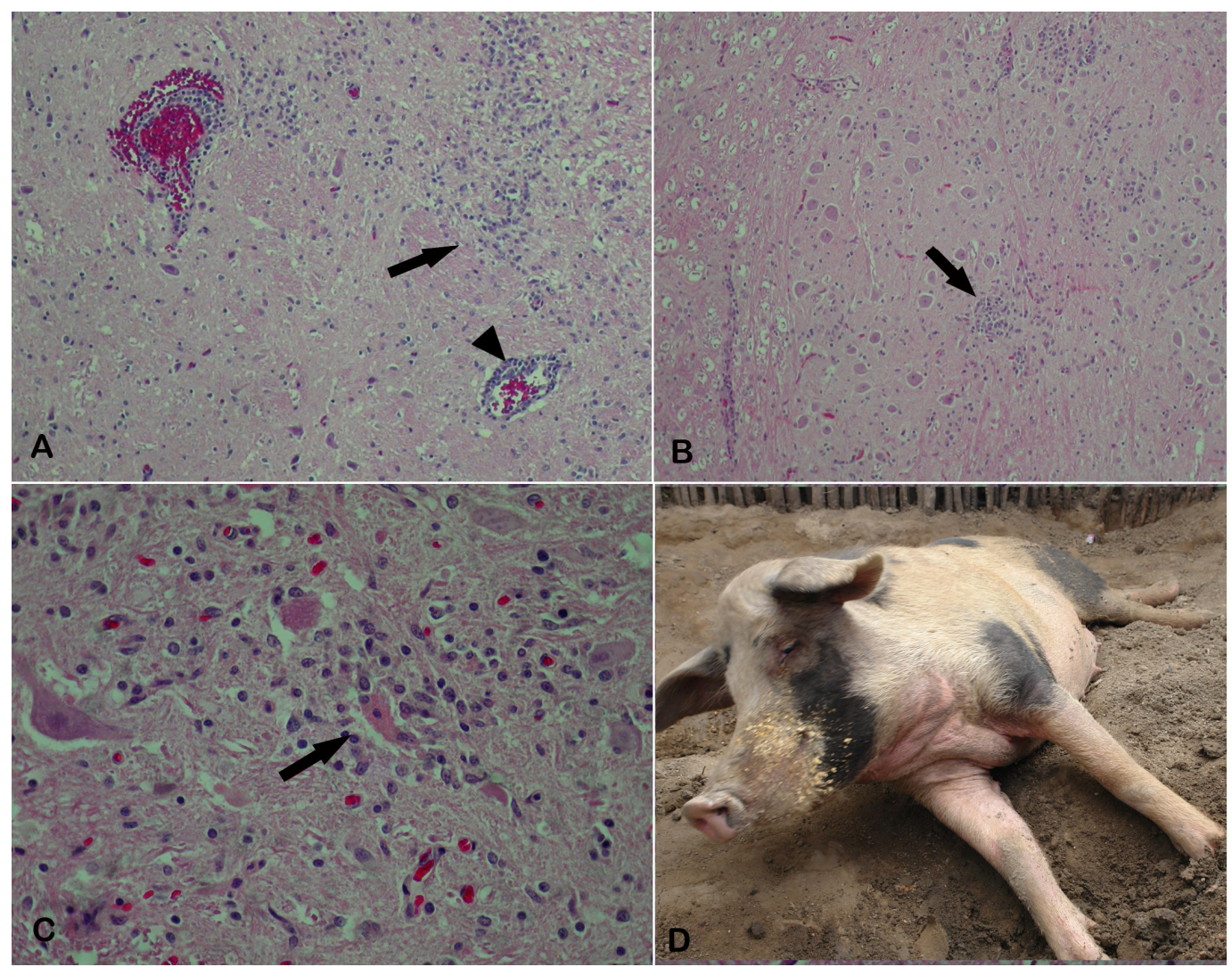

Figure 1. Rabies in pigs. A) Rostral colliculi, Pig 1. B) Medulla oblongata, Pig 1. C) Thoracic spinal cord, Pig 1. Focal gliosis (A and B) (arrows), perivascular cuffing (A-arrow head), and neuronophagia (C) (arrow) are observed. HE, x10 (A and B), and x40 (C). D) Pig 2 showing paralysis of the hind legs and recumbence.

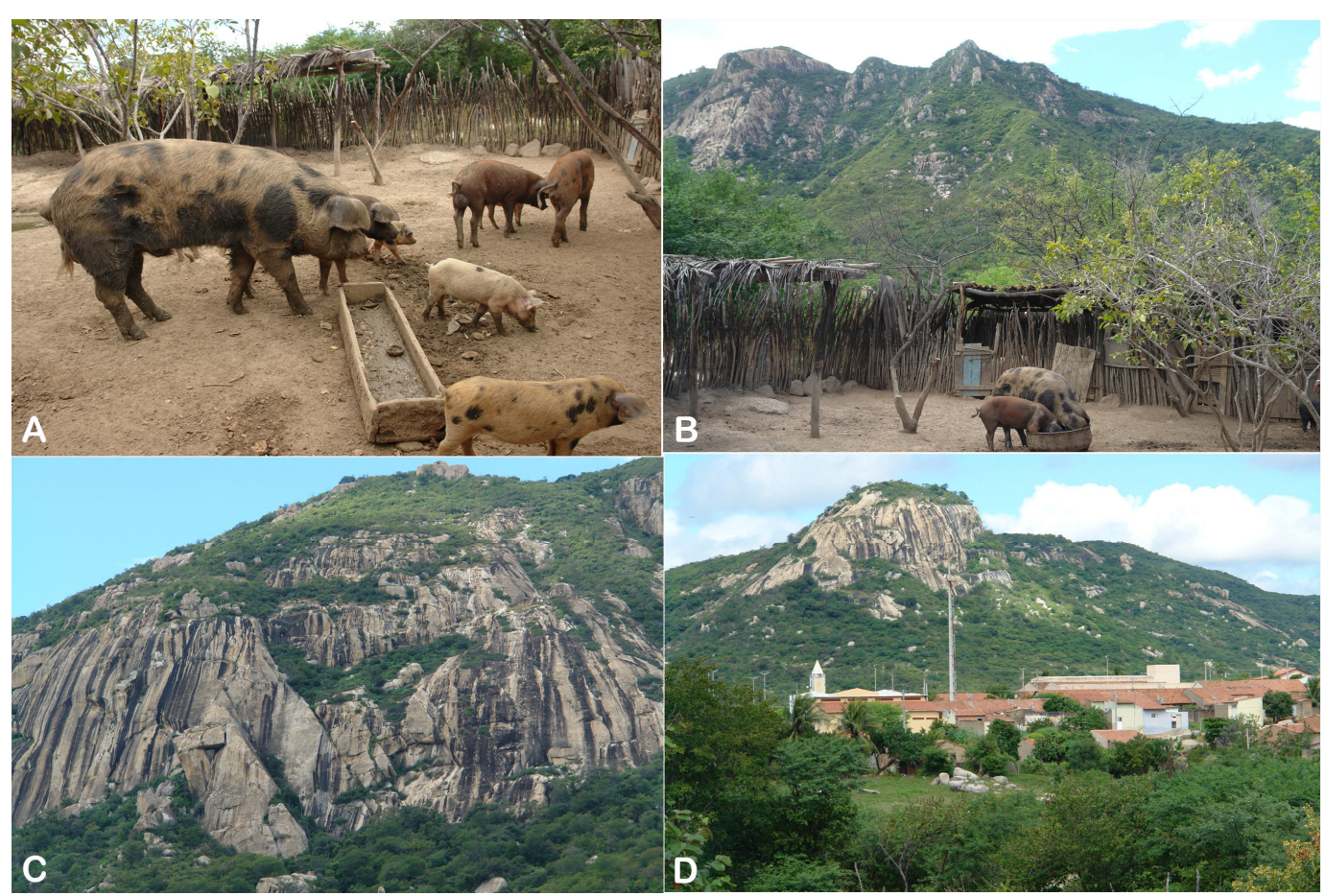

Figure 2. The aspect of the piggery (A and B) and the town (D) surrounded by mountains with caves, rocks and covered by the native forest (B, C and D). 


\section{REFERENCES}

1. Baer, G.M. (1991). Vampire bat and bovine paralytic rabies, p. 389-404 In: BAER, G. M. The natural history of rabies. 2 ed. CRC, Boca Raton. $620 \mathrm{p}$.

2. Barbosa, T.F.S.; Medeiros, D.B.A.; Travassos da Rosa, E.S.; Casse, L.M.N.; Medeiros, R.; Pereira, A.S.; Vallinoto, A.C.R.; Vallinoto, M.; Begot, A.L.; Lima, R.J.S.; Vasconcelos, P.F.C.; Nunes, M.R.T. (2008). Molecular epidemiology of rabies virus isolated from different sources during a bat-transmitted human outbreak occurring in Augusto Correa municipality, Brazilian Amazon. Virol. 370, 228-236.

3. Costa, W.A.; Ávila, C.A.; Valentine, E.J.G.; Reichmann, M.L.A.B.; Cunha, R.S.; Guidolin, R.; Panachão, M.R.I.; Omoto, T.M.; Bolzan, V.L. (1999). Profilaxia da raiva humana. Manual Técnico do Instituto Pasteur - n.4

4. Dean, D.J.; Abelseth, M.K.; Atanasiu, P. (1996). The fluorescent antibody test. In: Meslin, F-X., Kaplan, M.M., Koprowski, H. Laboratory techniques in rabies. 4. ed. Geneva: World Health Organization, pp. 88-95.

5. DuVernoy, T.S.; Mitchell, K.C.; Myers, R.A.; Walinski, L. W.; Tinsley, M.O. (2008). The first laboratory-confirmed rabid pig in Maryland, 2003. Zoon. Pub. Health. 55, 431-435.

6. Goldwasser R.A.; Kissling R.E. (1958). Fluorescent antibody staining of street and fixed rabies virus antigens. Proc. Soc. Exp. Biol. Med. 98, 219-223.

7. Gomes, A.A.B. (2004). Epidemiologia da raiva: caracterização de vírus isolados de animais domésticos e silvestres do semi-árido paraibano da região de Patos, Nordeste do Brasil. São Paulo, Brasil, 107p. (Thesis, Faculdade de Medicina Veterinária e Zootecnia, Universidade de São Paulo).

8. Ito, M.; Itou, T.; Shoji Y.; Sakai, T.; Ito, F.H.; Arai,Y.T.; Takasaki, T.; Kurane, I. (2003). Discrimination between dog-related and vampire batrelated rabies viruses in Brazil by strain-specific reverse transriptasepolymerase chain reaction and restriction fragment length polymorphism analysis. J. clin. virol. 26, 317-330.

9. Jiang, Y.; Yu, X.; Wang, L.; Lu, Z.; Liu, H.; Xuan, H.; Hu, Z.; Tu, C. 2008. Na outbreak of pig rabies in Hunan province, China. Epidemiol. Infect. 136, 504-508.

10. Koprowski, H. (1996). The mouse inoculation test. In: World Health Organization. Laboratory techniques in rabies. 4 ed. Geneve: WHO, pp.
80-87.

11. Lima, E.F.; Riet-Correa, F.; Castro, R.S.; Gomes, A.A.B.; Lima, F.S. (2005). Sinais clínicos, distribuição das lesões no sistema nervoso e epidemiologia da raiva em herbívoros na região Nordeste do Brasil. Pesq. Vet. Bras. 25 (4): 250-264.

12. Macedo, C.I.; Carnielli, P.Jr.; Brandão, P.E.; Travassos da Rosa, E.; Oliveira, R.N.; Galera, J.; Medeiros, R.; Machado, R.; Oliveira, R.C.; Carrieri, M.L.; Kotait, I. (2006). Diagnosis of Human Rabies Cases by Polymerase Chain Reaction of Neck-Skin Samples. Braz. J. Infect. Dis. $10(5), 341-345$.

13. Morehouse, L.G.; Kintner, L.D.; Nelson, S.L. (1968). Rabies in swine. $J$ Am. Vet Med Assoc. 153:57-64.

14. Ministério da Saúde. Raiva humana transmitida por morcegos no estado do Pará e Maranhão. Acesso: www.saude.gov.br/svs 22-02-2010.

15. Nociti, D.L.P.; Caramori Júnior, J.G.; Matta G.C.A.; Aguiar, D.M. (2009). Raiva em suíno no estado de Mato Grosso - relato de infecção conjunta com bovino da mesma propriedade. Arq. Inst. Biol. 76 (2), 269271.

16. Prins, L.; Yates, W.D.G. (1986). Rabies in Western Canada, 1978-1984. Can. Vet. J. 27, 164-169.

17. Queiroz, L.H.; de Carvalho, C.; Buso, D.S.; Ferrari C.I.L.; Pedro W.A. (2009). Perfil epidemiológico da raiva na região Noroeste do Estado de São Paulo no período de 1993 a 2007. Rev. Soc. Bras. Med. Trop. 42(1), 9-14.

18. Silva, R.O.S.; Costa Filho, R.B.; Pessoa, L.C.D.; Pires, P.S.; Salvarani, F.M.; Soares Filho, P.M.; Assis R.A.; Lobato, F.C.F. (2008). Surto de raiva em suínos em Miracema, Tocantins, Brasil. Ciênc. .Vet. Trop, 11 (2/3), 73-75.

19. Summers, B.A; Cummings, J.F.; Lahunta, A. (1994). Inflamatory diseases of the central nervous system. p. 95-188.In:Veterinary Neurophatology. Mosby, St. Louis, MO.

20. Tamura, K.; Dudley, J.; Nei, M. (2007). S MEGA4: Molecular Evolutionary Genetics Analysis (MEGA) software version 4.0. Molecular Biology and Evolution. 24, 1596-1599.

21. Teixeira, T.F.; Holz, C.L.; Caixeta, S.P.M.B.; Dezen, D.; Cibulski, S.P.; Silva, J.R.; Rosa, J.C.A.; Schmidt, E.; Ferreira, J.C.; Batista, H.B.C.R.; Caldas, E.; Franco, A.C.; Roehe, P. M. (2008). Diagnóstico de raiva no Rio Grande do Sul, Brasil, de 1985 a 2007. Pesq. Vet. Bras. 28(10),515520 .

22. Yates, W. D. G.; Rehmtulla, A. J.; McIntosh, D. W. (1983). Porcine rabies in Western Canada. Can. Vet. J. 24, 162-163. 